[Agr. Biol. Chem., Vol. 36, No. 9, p. 1581 1593, 1972]

\title{
Preparation and General Properties of Glucoamylase Bound to Halogenacetyl Cellulose ${ }^{\dagger}$
}

\author{
By Hidekatsu MAeda and Hideo Suzukr
}

Fermentation Research Institute, Inage, Chiba, Japan

Received January 18, 1972

\begin{abstract}
The coupling reaction of glucoamylase and halogenacetyl cellulose (HAC) without pretreating with organic solvent led to form large particles of immobilized glucoamylase and the activity and the specific activity of the preparation were very low. However, the coupling reaction with $\mathrm{HAC}$ pretreated with organic solvents allowed to form very fine particles and the activity was increased by five times. The latter contained $3 \sim 6 \%$ of enzyme protein and the specific activity to maltose reached to $80 \sim 90 \%$ of native glucoamylase. Since the specific activity of the preparation was presumed to be much influenced by the particle size, the specific activity and general properties of different particle sizes were compared with those of native enzyme. The specific activities of particles of $0 \sim 15 \mu, 15 \sim 55 \mu, 70 \sim 190 \mu$ and $130 \sim 270 \mu$ showed $82 \%, 33 \%, 27 \%$ and only $7 \%$ of native enzyme, respectively. $K m$ values of native form, $0 \sim 15 \mu, 15 \sim 55 \mu$ and $70 \sim 190 \mu$ particles were $0.90 \div 10^{-3} \mathrm{M}, 1.35 \% 10^{-3} \mathrm{M}, 1.60 \div 10^{-3} \mathrm{M}$ and $2.1510^{-3} \mathrm{M}$ in the case of maltose as substrate, respectively. The other properties of particles of $0 \sim 15 \%$ were almost identical to those of native enzyme except for the effect of temperature on the reaction rate. However, $\mathrm{pH}$ activity, $\mathrm{pH}$ stability and urea stability of particles of $70 \sim 190 \mu$ were much inferior to those of native enzyme and particles of $0 \sim 15 \mu$.
\end{abstract}

Many studies have been reported on the preparations and the properties of insoluble enzymes. ${ }^{1,2}$ Glucoamylase was also immobilized by physical adsorption to activated carbon $^{3 j}$ and by ionic adsorption to DEAEcellulose. ${ }^{4}$ In the previous paper, ${ }^{5)}$ the authors reported the general properties of immobilized glucoamylase which was prepared by coupling the native form to carboxymethyl cellulose(CMC)-azide. Further, the authors reported that glucose was produced continuously from the column packed with CMC-glucoamylase and sawdust by passing $35 \%$ liquified starch solution. However, the preparation of CMC-azide from CMC was complicated and the enzyme content of the resulted preparation was only $2 \%$. The coupling reaction of glucoamylase to halo-

\footnotetext{
I Studies on Water-insoluble Enzyme. Part III.
}

genacetyl cellulose was selected as a way to prepare insoluble glucoamylase with a simpler process and to get a preparation of higher enzyme content. This coupling reaction was reported by $A$. Patchornik ${ }^{7}$ to prepare insoluble trypsin and chymotrypsin, but the detailed information has not yet been reported. In this paper, the authors report that the preparation of immobilized glucoamylase using $\mathrm{HAC}$ was improved to get higher activity of immobilized glucoamylase and that the specific activity and some general properties of the preparations were much influenced by its particle size.

\section{MATERIALS AND METHODS}

1. Materials. Glucoamylase originating from Rhizopus niveus was purchased from Seikagaku Kogyo Co., Ltd. It contained over $95 \%$ of protein and was homogeneous on Tiselius electrophoresis. The specific 
activity to maltose was $5.5 \mathrm{U} / \mathrm{mg}$ and that to amylose was $18 \mathrm{U} / \mathrm{mg}$. These values of specific activitiy are often quoted as original activities in this paper. Crystalline trypsin was a product of Boehringer Co., Ltd and the specific activity to casein was $920 \mathrm{U} / \mathrm{mg}$. The definition of enzyme unit will be described later. Microcrystalline cellulose preparations were used for thin-layer chromatography (Avicel TL) and column chromatography (Avicel CC). The former had particle size of $0 \sim 50 \mu$ in diameter and the latter had particle size of $20 \sim 300 \mu$ in diameter. The microcrystalline cellulose was purchased from Asahi Chemical Industry Co., Ltd.

2. Fractionation of particles of microcrystalline cellulose. Avicel TL was fractionated into equal weight of small and large particles by sedimentation in methanol. Avicel CC was fractionated into each particle size by sifting.

3. Preparation of amylose. Amylose was prepared by Azumi's method ${ }^{8\}}$ to separate amylose as buthanol complex.

4. Assay of glucoamylase activity. Standard condition of enzyme assay was carried out at $40^{\circ} \mathrm{C}$ by the method previously described.5) One unit was defined as the amount of enzyme releasing 1 mole of glucose in one minute at $\mathrm{pH} 4.5$ at $40^{\circ} \mathrm{C}$. The effects of enzyme concentration of glucoamylase bound to bromoacetyl cellulose (BAC-glucoamylase) on the reaction rates to maltose and to amylose are shown in Fig. 1 and 2 respectively.

5. Determination of $\mathrm{Km}$. Michaelis constant was determined by the method previously described. ${ }^{5)}$

6. Assay of caseinolytic activity. The enzyme reaction was carried out by incubating a mixture of $5 \mathrm{ml}$ of $0.6 \%$ casein solution dissolved in $0.05 \mathrm{M}$ phosphate buffer $(\mathrm{pH} 7.0)$ and $1 \mathrm{ml}$ of native enzyme solution or suspension of insoluble enzyme at $30 . \mathrm{C}$ for $10 \mathrm{~min}$. The incubation was static in the case of native enzyme and was shaken at $130 \mathrm{rpm}$ in the case of insoluble enzyme. The enzyme reaction was stopped by adding $5 \mathrm{ml}$ of the solution containing $0.11 \mathrm{M}$ trichloroacetic acid, $0.22 \mathrm{M}$ sodium acetate and $0.33 \mathrm{M}$ acetic acid. The absorbance of the supernatant at $275 \mathrm{~m} /$ was measured. One unit was defined as the activity liberating the hydrolysate which was corresponded to absorbance of $1 / \mathrm{g}$ of tyrosine for one minute by the enzyme.

7. Assay of protein content in insoluble enzyme.

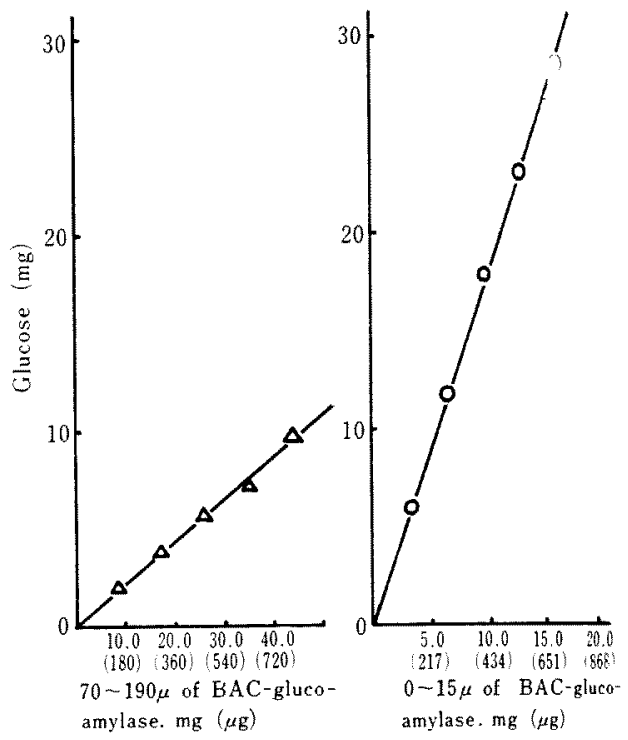

FIG. 1. Effect of Concentration of BAC-GlucoamyIase on the Reaction Rate: Substrate; Maltose.

BAC-glucoamylase: Glucoamylase bound to bromoacetyl cellulose. The enzyme assay was carried out under standard conditions with varied amounts of enzyme. Figures in ( ) are the amounts of bound enzyme.

- $\bigcirc$ BAC-glucoamylase of $0 \sim 15 \mu$.

$\triangle-\triangle B A C$-glucoamylase of $70 \sim 190 \mu$

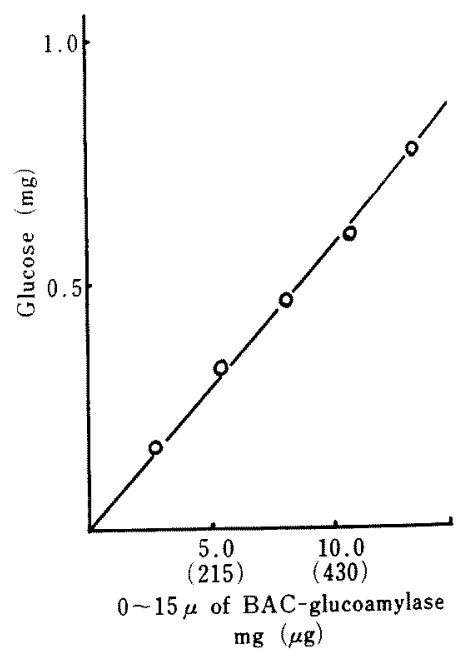

FIG. 2. Effect of Concentration of BAC-Glucoanylase on the Reaction Rate: Substrate; Amylose.

The enzyme assay was carried out under standard conditions with varied amounts of enzyme. Figure in ( ) are the amounts of bound enzyme.

$O-O$ BAC-glucoamylase of $0 \sim 15 \mu$. 
Five $\mathrm{ml}$ of the suspension of insoluble enzyme was added to the digestion flask and was condensed to $1 \sim 2 \mathrm{~m} /$ by heating. After the addition of $20 \mathrm{mg}$ of cupper sulfate, $180 \mathrm{mg}$ of potassium sulfate and $3 \mathrm{ml}$ of conc. sulfuric acid to it, the mixture was digested by heating vigorously for $3 \mathrm{hr}$. After digestion, the mixture was diluted with distilled water and was adjusted to $\mathrm{pH} 12 \sim 13$ by sodium hydroxide solution. The cupper hydroxide formed was removed by filtration and nitrogen in the filtrate was determined by Morita and Kogure's method. ${ }^{91}$ The value multiplied the amount of nitrogen by 6.25 was regarded as the amount of bound enzyme.

In the case of the sample containing iodine, the pretreatment was carried out before digestion as follows. Five $\mathrm{ml}$ of the suspension and $0.5 \mathrm{ml}$ of $20 \%$ sodium hydroxide solution were added to the digestion flask and the mixture was condensed to $1 \sim 2 \mathrm{ml}$ by heating. After cooling, $1 \mathrm{ml}$ of conc. sulfuric acid and several drops of $30 \%$ hydrogen peroxide solution were added to the mixture.

8. Assay of bromine and iodine. Bromine was determined by Ota's method using the combustion flask. ${ }^{101}$ Iodine was determined by colorimetry, ${ }^{11}$ after $15 \mathrm{mg}$ of iodoacetyl cellulose was boiled with $20 \mathrm{ml}$ of $0.1 \mathrm{~N}$ sodium hydroxide solution in the beaker.

9. Determination of particle size of insoluble enzyme. One or two drops of uniform suspension of insoluble enzyme was taken on a slide glass and photographs of several hundred of particles were taken at random using microscopy. The number frequency was determined by the following method. The major diameter of particles in photograph was measured and particles were assorted at regular intervals, such as $5 \mu, 10 \mu$ or $20 \mu$. Secondly, the ratio of minor diameter to major diameter of particles in each sample was measured and its average was calculated. The result was 0.667 for glucoamylase bound to bromoacetyl cellulose of $0 \sim 15 \mu, 0.5$ for $15 \sim 55 \mu, 0.333$ for $70 \sim 190 \mu$ and 0.667 for $130 \sim 270 \mu$, respectively. The weight frequency was determined as follows.

$$
f w(\% / \mu)=\frac{D p^{3} \cdot(S d / L d)^{2} f n}{\sum D p^{3} \cdot(S d / L d)^{2}} f n
$$

$f w$, the weight frequency at regular intervals.

$f n$, the number frequency at regular intervals.

$D p$, mean major diameter of particles at regular intervals.
$(S d / L d)$, the ratio of minor diameter to major diameter.

10. Preparation of halogenacetyl cellulose (HAC).

1) Preparation of Bromoacetyl cellulose (BAC). Particles below 350 mesh, $350 \sim 150$ mesh and $150 \sim$ 100 mesh fractionated from Avicel TL and Avicel CC were bromoacetylated as follows, respectively. The mixture of $4.5 \mathrm{~g}$ of cellulose, $25 \mathrm{~g}$ of bromoacetic acid and $15 \mathrm{ml}$ of dioxane was stirred overnight at room temperature. Then, $25 \mathrm{~g}$ of bromoacetyl bromide was added and the mixture was stirred for $8 \mathrm{hr}$ at $10 \sim$ $20 \mathrm{C}$. This mixture was poured into ice water and the white precipitate formed was washed several times with distilled water, aqueous sodium bicarbonate solution and then again with water. The product was sifted out in water and was dried in vacuum. These bromine content was $8-16 \%$.

2) Preparation of iodoacerylcellulose (IAC). The mixture contained $6 \mathrm{~g}$ of sodium iodide, $50 \mathrm{ml}$ of ethanol and $2 \mathrm{~g}$ of BAC prepared from small particles in Avicel TL (abbrebiated as BAC (small)) was stirred overnight at room temperature to replace bromine in BAC by iodine. The product was washed with ethanol, aqueous sodium bicarbonate solution and then again with ethanol and was dried in vacuum. The iodine content was $19 \%$ and the bromine content was below $1 \%$.

11. Standard preparation of insoluble enzyme. As a carrier $300 \mathrm{mg}$ of BAC or IAC was suspended in $2 \mathrm{ml}$ of water or organic solvent. In the latter, a part or all of BAC or IAC was dissovled into organic solvents. Organic solvents and water thus used were simply refered to as solvent. Twenty $\mathrm{ml}$ of $0.1 \mathrm{~m}$ phosphate buffer ( $\mathrm{pH} 8.4$ ) and $18 \mathrm{ml}$ of enzyme solution containing $30 \mathrm{mg}$ of enzyme were added to the above suspension and the coupling reaction was carried out on a stirrer at $5^{\circ} \mathrm{C}$ overnight. The product was washed with distilled water, $0.5 \mathrm{M}$ phosphate buffer ( $\mathrm{pH} 6.0$ ) and then again with distilled water and was stored as the aqueous suspension of water at $5^{\circ} \mathrm{C}$. Glucoamylase bound to $\mathrm{BAC}$ was denoted as $\mathrm{BAC}$-glucoamylase and glucoamylase bound to IAC as IAC-glucoamylase.

12. Preparation of various particle size of $B A C$ glucoamylase

1) Particles of $0 \sim 15 \mu$. BAC-glucoamylase of $0 \sim 15$ " was prepared under standard condition by using $\mathrm{BAC}$ (small) and dimethylsulfoxide (DMSO) as solvent and was fractionated by sedimentation in water. Particles of $0 \sim 15 \mu$ could also be obtained by 
the another method as follows. The BAC-glucoamylase was prepared under standard preparation by using water as solvent after crashing $300 \mathrm{mg}$ of BAC with $300 \mathrm{mg}$ of silica sand in a mortar and the particles of $0 \sim 15 \mu$ were fractionated by sedimentation.

2) Particles of $15 \sim 55 \mu$. BAC-glucoamylase of 15 $\sim 55 \mu$ was prepared under standard preparation by using particles of BAC smaller than 350 mesh and water as solvent and was fractionated by sedimentation in water.

3) Particles of $70 \sim 190 \mu$ and $130 \sim 270 \mu$. BACglucoamylases of $70 \sim 190 \mu$ and $130 \sim 270 \mu$ were prepared by the following method. The reaction mixture of $300 \mathrm{mg}$ of $350 \sim 150$ mesh of BAC or $150 \sim 100$ mesh of BAC, $2 \mathrm{ml}$ of glucoamylase solution dissolved $30 \mathrm{mg}$ of enzyme and $1 \mathrm{ml}$ of $0.1 \mathrm{M}$ phosphate buffer $(\mathrm{pH}$ 8.4) was shaken overnight at $5 \mathrm{C}$ after adjusting to $\mathrm{pH} 6.5 \sim 7.5$. The product was washed as described in the standard preparation and was shifted in water to each particle size.

\section{RESULTS}

\section{Preparation of BAC-glucoamylase}

1. Effects of organic solvents. BACglucoamylase was prepared according to A. Patchornik's report ${ }^{73}$ by using water as solvent, however, its activity was low and the protein content was only $2.5 \%$ Accordingly, as a result of investigation for the purpose of increasing the activity and the protein content they could be increased by the procedure as follows. BAC was suspended in organic solvents instead of water and part or all of BAC was dissolved at first and the dissolved $B A C$ was regenerated by adding buffer solution to it. The high activity of BAC-glucoamylase was prepared by coupling glucoamylase to the regenerated $\mathrm{BAC}$. The results are shown in Table I. Among organic solvents, DMSO and methylcellosolve were very effective and the activities were increased by about four times and about five times, respectively, by using BAC regenerated from DMSO and methylcellosolve. The specific activities of these preparations increased by three times and the protein contents could be also increased. They were stable in aqueous suspension for several months at $5^{\circ} \mathrm{C}$.

\section{Effect of $p H$ and enzyme concentration} on the amount of bound enzyme. Glucoamylase was immobilized at varying $\mathrm{pH}$ values in Table II by using BAC(small) and acetone as the solvent and the effect of $\mathrm{pH}$ was investigated. The preparation at $\mathrm{pH} 8.4$ contained the highest amount of bound enzyme.

Glucoamylase was immobilized by using BAC (small) and from $10 \mathrm{mg}$ to $40 \mathrm{mg}$ of glucoamylase as shown in Table III and the effect of enzyme concentration was investigated. The amount of bound enzyme increased in proportion to the increase of enzyme concentration (as shown in Table III), but the remained enzyme in the reaction mixture also increased in proportion to it.

Subsequently, glucoamylase was immobilized by decreasing the volume of the reaction mixture, keeping constantly the amount of added enzyme as follows. After $300 \mathrm{mg}$ of BAC (small) was dissolved into $1 \mathrm{ml}$ of DMSO, $1 \mathrm{ml}$ of acetone was added to the solution. After cooling at $5^{\circ} \mathrm{C}, 1 \mathrm{ml}$ of $0.5 \mathrm{~m}$ phosphate buffer ( $\mathrm{pH} \mathrm{8.4)}$ and $5 \mathrm{ml}$ of enzyme solution containing $30 \mathrm{mg}$ of glucoamylase were added to the suspension and then incubated and stirred overnight at $5^{\circ} \mathrm{C}$. The product was washed according to the standard procedure. A yield of $285 \mathrm{mg}$ of BACglucoamylase was obtained. The protein content of the preparation increased to $5.9 \%$ and the total activity to maltose was $55 \mathrm{U}$. The specific activity was $3.4 \mathrm{U} / \mathrm{mg}$ and was $62 \%$ of original activity. The protein content could be increased to $5.9 \%$ by this procedure.

\section{Preparation of IAC-glucoamylase}

Glucoamylase was immobilized according to the standard procedure by using IAC as a carrier and the preparations were com- 


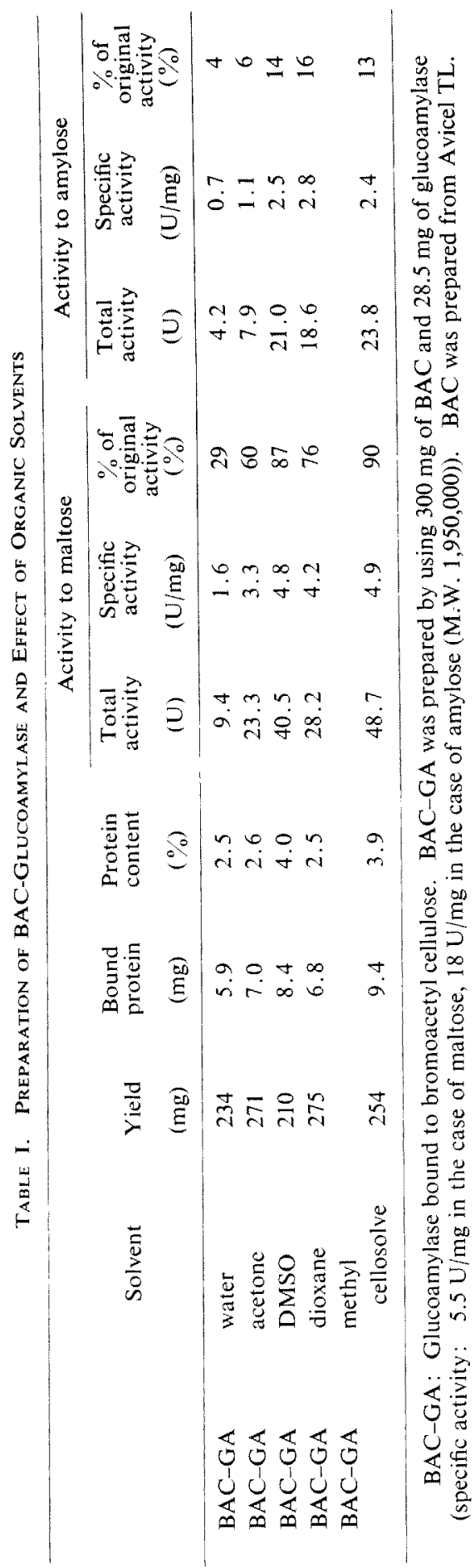

pared with those from BAC. As for the protein content and the activity, the data of IAC-glucoamylase were almost identical to those of BAC-glucoamylase as shown in Table IV. Considering the organic solvents, acetone and DMSO were also effective and DMSO was superior in this case.

\section{Effect of particle size on the activity}

Since the particle size of BAC-glucoamylase prepared by using water as the solvent was observed to be much larger than that of BACglucoamylase prepared by using organic solvents, the particle size was presumed to be closely related to the specific activity. Although it was ideal to fractionate particles to every size from the same sample of BACglucoamylase by any method, it is very difficult in practice. Accordingly, each particle of BAC-glucoamylase was prepared as described in experimental methods and the relation between particle size and the specific activity was investigated. The results are shown in Table $\mathrm{V}$ and the descriptions of the particle size used in this work are shown in Table VI and Table VII. The data in Table V indicate that the specific activities of particles were much influenced by their own particle size. Especially, the specific activity of particles of $0 \sim 15 \mu$ showed over $60 \%$ of original activity. Whereas the specific activity was only $7 \%$ of original activity in the case of particles of $130 \sim 270 \mu$. However, in the case of particles of $0 \sim 15 \mu$, the specific activity seemed to be slightly influenced by their protein content, therefore the protein content might be a factor to influence the specific activity.

\section{General properties of BAC-glucoamylase}

The general properties of BAC-glucoamylase of $0 \sim 15 \mu$ prepared by using DMSO as the solvent and BAC-glucoamylase of $70 \sim 190 \mu$ 
Table II. The pH Dependence of the Binding of Glucoamylase on Bromoacetyl Cellulose

$\begin{array}{cccccccc}\text { Exp. No. } & \begin{array}{c}\text { pH in the } \\ \text { mixture }\end{array} & \begin{array}{c}\text { BAC- } \\ (\text { small)-GA } \\ (\mathrm{mg})\end{array} & \begin{array}{c}\text { Bound } \\ \text { enzyme } \\ (\mathrm{mg})\end{array} & \begin{array}{c}\text { Protein } \\ \text { content } \\ (\%)\end{array} & \begin{array}{c}\text { Total } \\ \text { activity } \\ (\mathrm{U})\end{array} & \begin{array}{c}\text { Specific } \\ \text { activity } \\ (\mathrm{U} / \mathrm{mg})\end{array} & \begin{array}{c}\% \text { of original } \\ \text { activity } \\ (\%)\end{array} \\ 1 & \mathrm{pH} 8.4 & 280 & 7.3 & 2.6 & 38.6 & 5.3 & 96 \\ 2 & \mathrm{pH} 7.0 & 302 & 6.3 & 2.1 & 26.6 & 4.3 & 78 \\ 3 & \mathrm{pH} 5.5 & 287 & 6.4 & 2.2 & 27.6 & 4.3 & 78 \\ 4 & \mathrm{pH} \mathrm{4.0} & 275 & 4.8 & 1.7 & 23.4 & 4.9 & 89\end{array}$

BAC(small)-GA: Glucoamylase bound to bromoacetyl cellulose (small). BAC(small)-GA was prepared by using $300 \mathrm{mg}$ of BAC(small), $28.5 \mathrm{mg}$ of glucoamylase and acetone as the solvent. BAC(small) was prepared from small particles in Avicel TL. The reaction mixtures were buffered at $\mathrm{pH}$ shown by $0.1 \mathrm{M}$ phosphate buffer $(\mathrm{pH} 8.4$ and $\mathrm{pH} 7.0$ ) and $0.2 \mathrm{M}$ acetate buffer ( $\mathrm{pH} 5.5$ and $\mathrm{pH} 4.0$ ).

Table III. Relation between the Amount of Glucoamylase and Bound Glucoamylase

\begin{tabular}{|c|c|c|c|c|c|c|c|}
\hline \multirow[b]{2}{*}{ Exp. No. } & \multirow[b]{2}{*}{$\begin{array}{c}\text { Native enzyme } \\
\text { added }(A) \\
(\mathrm{mg})\end{array}$} & \multirow[b]{2}{*}{$\begin{array}{c}\text { BAC(small) } \\
\text { GA } \\
(\mathrm{mg})\end{array}$} & \multirow[b]{2}{*}{$\begin{array}{c}\text { Bound } \\
\text { enzyme(B) } \\
\text { (mg) }\end{array}$} & \multirow[b]{2}{*}{$\begin{array}{c}(\mathrm{B}) /(\mathrm{A}) \\
(\%)\end{array}$} & \multicolumn{3}{|c|}{ Activity to maltose } \\
\hline & & & & & $\begin{array}{l}\text { Total } \\
\text { activity } \\
\text { (U) }\end{array}$ & $\begin{array}{l}\text { Specific } \\
\text { activity } \\
(\mathrm{U} / \mathrm{mg})\end{array}$ & $\begin{array}{l}\% \text { of original } \\
\text { activity } \\
(\%)\end{array}$ \\
\hline 1 & 10 & 275 & 5.6 & 56 & 26.1 & 4.7 & 85 \\
\hline 2 & 20 & 277 & 7.4 & 37 & 33.5 & 4.5 & 82 \\
\hline 3 & 30 & 285 & 10.9 & 36 & 39.6 & 3.6 & 65 \\
\hline 4 & 40 & 273 & 11.7 & 27 & 50.0 & 4.3 & 78 \\
\hline
\end{tabular}

BAC(small)-GA was prepared by using $300 \mathrm{mg}$ of BAC(small), acetone as the solvent and each amount of glucoamylase.

were compared with those of native glucoamylase.

1. Km. Km of native glucoamylase and BAC-glucoamylase of $0 \sim 15 \mu, 15 \sim 55 \mu$ and $70 \sim 190 \mu$ was determined. In the case of maltose as substrate, $\mathrm{Km}$ of native one, BACglucoamylase of $0 \sim 15 \mu, 15 \sim 55 \mu$ and $70 \sim$ $190 \mu$ was $0.90 \times 10^{-3} \mathrm{M}, 1.35 \times 10^{-3} \mathrm{M}, 1.60 \times$ $10^{-3} \mathrm{M}$ and $2.15 \cdot 10^{-3} \mathrm{M}$, respectively. In the case of amylose as substrate, $\mathrm{Km}$ values of native one and BAC-glucoamylase of $0 \sim 15 \mu$ were $1.00 \times 10^{-7} \mathrm{M}$ and $1.50 \times 10^{-7} \mathrm{M}$, respectively. Activities to amylose of particles of $15 \sim$ $55 \mu$ and $70 \sim 190 \mu$ were so low that their $K m$ could not be estimated exactly. $K m$ of BACglucoamylase increased a little more than that of native enzyme and $K m$ of the large particles was recognized to have a tendency to increase a little, as compared with that of the small particles.

2. Effect of temperature on the reaction rate. Effect of temperature on the reaction rate of BAC-glucoamylase was almost identical to that of native enzyme in the case of maltose as the substrate as shown in Fig. 5. However, in the case of amylose as the substrate, the action of BAC-glucoamylase was inferior to that of native enzyme as shown in Fig. 6.

3. Heat stability. Their heat stability was almost identical to it of native enzyme as shown in Fig. 7. 

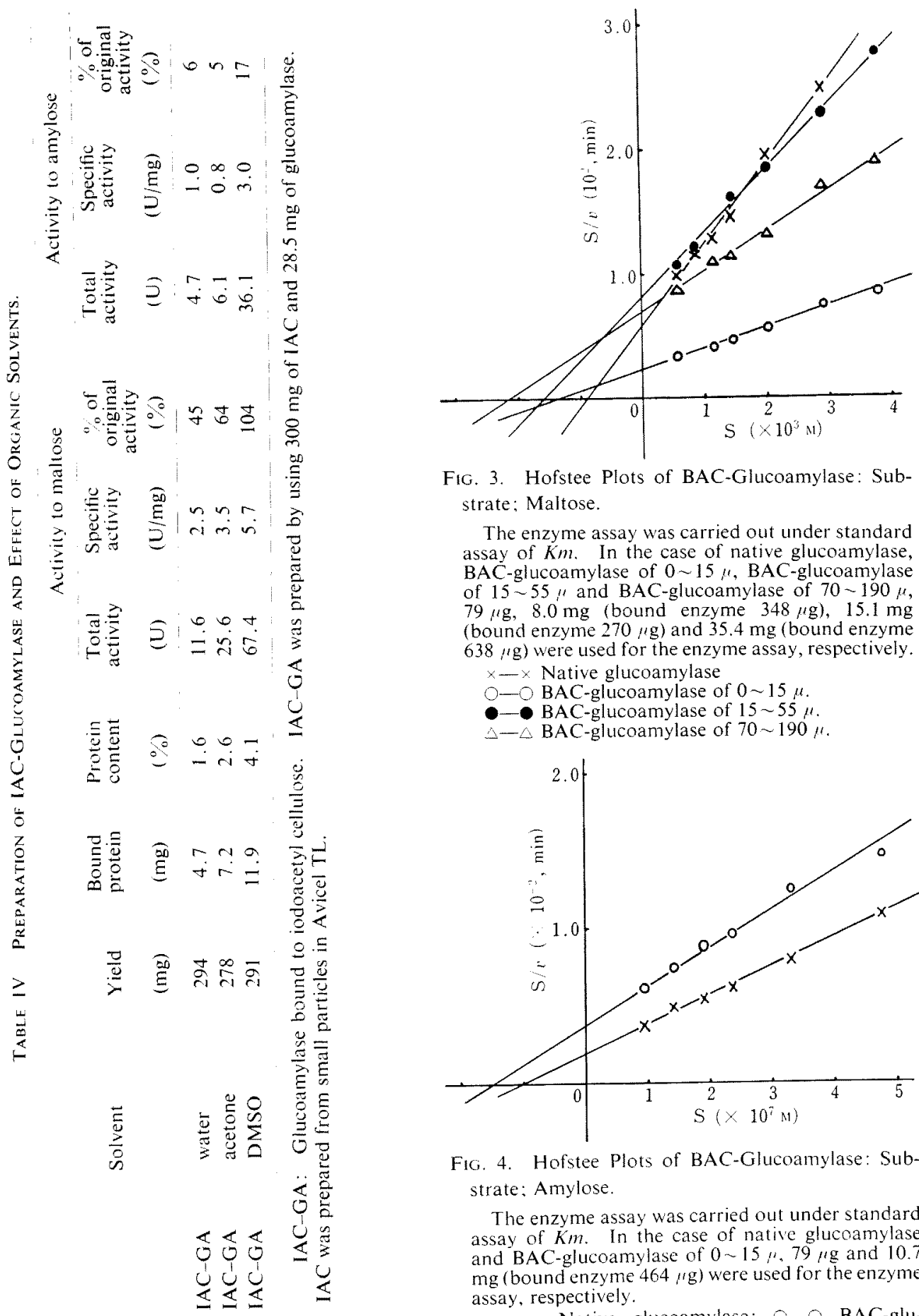

FIG. 3. Hofstee Plots of BAC-Glucoamylase: Substrate: Maltose.

The enzyme assay was carried out under standard assay of $K \mathrm{~m}$. In the case of native glucoamylase, BAC-glucoamylase of $0 \sim 15 \mu$, BAC-glucoamylase of $15 \sim 55 "$ and BAC-glucoamylase of $70-190 \mu$, $79 \mu \mathrm{g}, 8.0 \mathrm{mg}$ (bound enzyme $348 \mu \mathrm{g}$ ), $15.1 \mathrm{mg}$ (bound enzyme $270 \mu \mathrm{g}$ ) and $35.4 \mathrm{mg}$ (bound enzyme $638 \mathrm{~kg}$ ) were used for the enzyme assay, respectively. $x-x$ Native glucoamylase

$0-O$ BAC-glucoamylase of $0 \sim 15 \mu$.

- BAC-glucoamylase of $15 \sim 55 \mu$.

$\Delta-\triangle B A C$-glucoamylase of $70 \sim 190 \mu$.

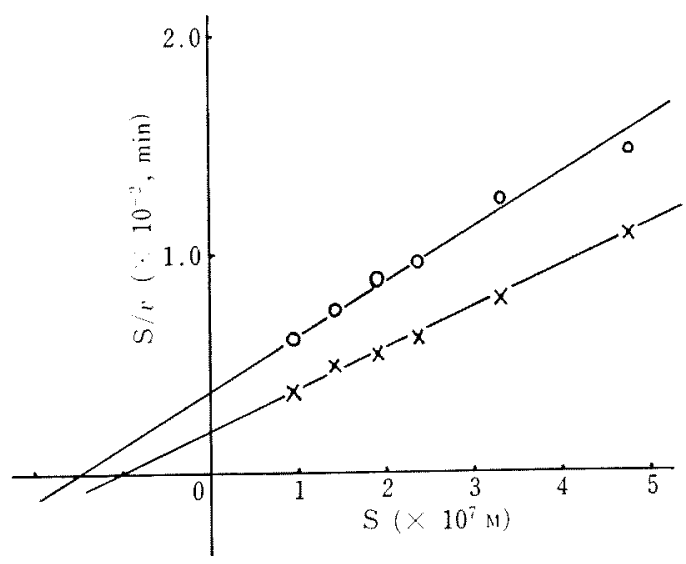

Fic. 4. Hofstee Plots of BAC-Glucoamylase: Substrate: Amylose.

The enzyme assay was carried out under standard assay of $\mathrm{Km}$. In the case of native glucoamylase and BAC-glucoamylase of $0-15 \mu, 79 \mu \mathrm{g}$ and 10.7 $\mathrm{mg}$ (bound enzyme $464, \mathrm{~g}$ ) were used for the enzyme assay, respectively.

$x-x$ Native glucoamylase; $0-0$ BAC-glucoamylse of $0-15 \%$. 


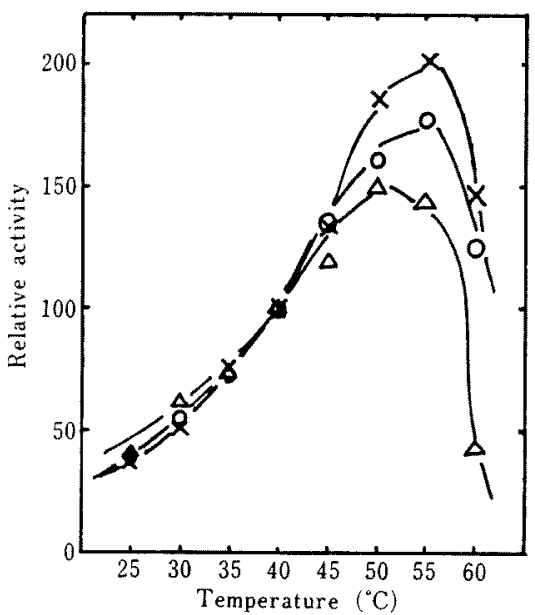

FIG. 5. Effect of Temperature on the Reaction Rate: Substrate; Maltose.

The enzyme assay was carried out under standard conditions except for each incubation temperature. The reaction rate obtained at $40^{\circ} \mathrm{C}$ was taken as $100 \%$. Respectively, $79 \% \mathrm{~g}$ of native glucoamylase, $4.0 \mathrm{mg}$ (bound enzyme $174 \mu \mathrm{g}$ ) of BAC-glucoamylase of $0 \sim 15 \mu$ and $16.4 \mathrm{mg}$ (bound enzyme $290 \mu \mathrm{g})$ of BAC-glucoamylase of $70 \sim 190 \mu$ were used for the enzyme assay.

$x$ - $x$ Native glucoamylase; $O-O$ BAC-glucoamylase of $0 \sim 15 \mu ; \triangle-\triangle$ BAC-glucoamylase of $70 \sim 190 \mu$.

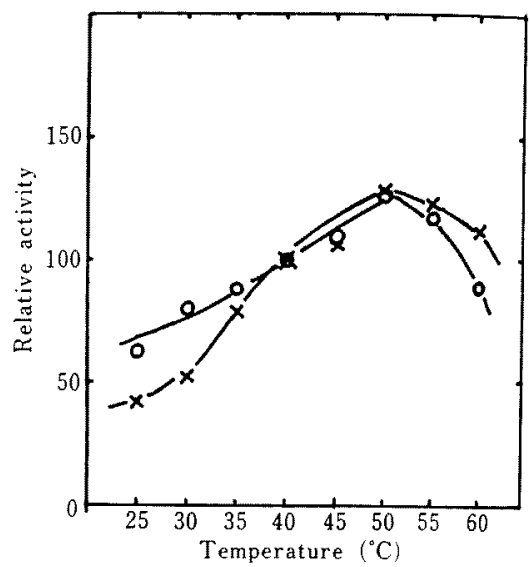

Fig. 6. Effect of Temperature on the Reaction Rate Substrate; Amylose.

The enzyme assay was carried out under standard conditions except for each incubation temperature. The reaction rate obtained at $40^{\circ} \mathrm{C}$ was taken as $100 \%$. In the case of native glucoamylase, $16 \mu \mathrm{g}$ was used for the enzyme assay. In the case of BAC-glucoamylase, $2.0 \mathrm{mg}$ (bound enzyme $87 \mu \mathrm{g}$ ) was used in range of $25^{\circ} \mathrm{C}$ to $45^{\circ} \mathrm{C}$ and $1.0 \mathrm{mg}$ (bound enzyme $44 \mu \mathrm{g}$ ) was used in range of $50^{\circ} \mathrm{C}$ to $60^{\circ} \mathrm{C}$.

$x-x$ Native glucoamylase; $\bigcirc-O$ BAC-glucoamylase of $0 \sim 15 \mu$.

Table V. Effect of Particle Size on the Activity

\begin{tabular}{|c|c|c|c|c|c|c|c|c|}
\hline & \multirow[b]{2}{*}{$\begin{array}{l}\text { Particle } \\
\text { size }\end{array}$} & \multirow[b]{2}{*}{$\begin{array}{c}\text { Protein } \\
\text { content } \\
(\%)\end{array}$} & \multicolumn{3}{|c|}{ Activity to maltose } & \multicolumn{3}{|c|}{ Activity to amylose } \\
\hline & & & $\begin{array}{l}\text { Activity } \\
\text { (U/g) }\end{array}$ & $\begin{array}{l}\text { Specific } \\
\text { activity } \\
\text { (U/mg) }\end{array}$ & $\begin{array}{l}\% \text { of } \\
\text { original } \\
\text { activity } \\
(\%)\end{array}$ & $\begin{array}{l}\text { Activity } \\
(\mathrm{U} / \mathrm{g})\end{array}$ & $\begin{array}{l}\text { Specific } \\
\text { activity } \\
(\mathrm{U} / \mathrm{mg})\end{array}$ & $\begin{array}{c}\% \text { of } \\
\text { original } \\
\text { activity } \\
(\%)\end{array}$ \\
\hline $\mathrm{BAC}-\mathrm{GA}(\mathrm{A})$ & $0 \sim 15$ & 4.3 & 194 & 4.5 & 82 & 91.0 & 2.1 & 12 \\
\hline $\mathrm{BAC}-\mathrm{GA}(\mathrm{B})$ & $0 \sim 15$ & 3.0 & 115 & 3.8 & 70 & 63.6 & 2.1 & 12 \\
\hline $\mathrm{BAC}-\mathrm{GA}(\mathrm{C})$ & $0 \sim 15$ & 1.2 & 39.8 & 3.3 & 60 & 22.9 & 2.0 & 11 \\
\hline $\mathrm{BAC}-\mathrm{GA}$ & $15 \sim 55$ & 1.8 & 32.4 & 1.8 & 33 & 13.1 & 0.73 & 4 \\
\hline $\mathrm{BAC}-\mathrm{GA}$ & $70 \sim 190$ & 1.8 & 26.5 & 1.5 & 27 & traces & - & - \\
\hline $\mathrm{BAC}-\mathrm{GA}$ & $130 \sim 270$ & 2.3 & 9.6 & 0.36 & 7 & $\underline{-}$ & - & - \\
\hline
\end{tabular}

The weight frequency distribution of particle size of the above BAC-GA and their preparations will be described in Table VI and Table VII. 


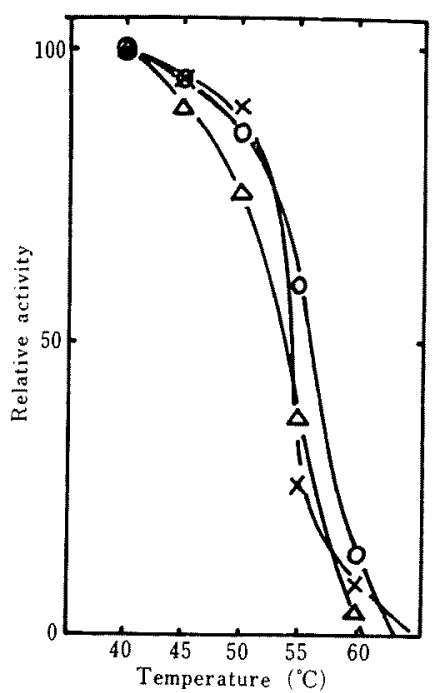

FIG. 7. Heat Stability.

A mixture of $1 \mathrm{ml}$ of enzyme solution or suspension and $4 \mathrm{ml}$ of $0.1 \mathrm{M}$ acetate buffer ( $\mathrm{pH} 4.5$ ) was preincubated for $15 \mathrm{~min}$ at each temperature, rapidly cooled and $5 \mathrm{ml}$ of $2 \%$ maltose solution was added for the enzyme assay. Respectively, $79 \mu \mathrm{g}$ of native glucoamylase, $4.0 \mathrm{mg}$ (bound enzyme $174 \mu \mathrm{g}$ ) of BAC-glucoamylase of $0 \sim 15 \mu$ and 8.7 mg (bound enzyme $156 \mu \mathrm{g}$ ) of BAC-glucoamylase of $70 \sim 190 \mu$ were used for the enzyme assay.

$x \rightarrow x$ Native glucoamylase; $0-0$ BAC-glucoamylase of $0 \sim 15 \mu ; \triangle \rightarrow \triangle$ BAC-glucoamylase of $70 \sim 190 \mu$.

4. $p H$ activity and $p H$ stability. Their optimum $\mathrm{pH}$ values were almost identical to it of native enzyme as shown in Fig. 8, however the reaction rate of BAC-glucoamylase of $70 \sim 190 \mu$ in the range of $\mathrm{pH} 2 \sim 4$ was inferior to them of native one and $\mathrm{BAC}$ glucoamylase of $0 \sim 15 \mu$.

Figure 9 showed that $\mathrm{pH}$ stability of BACglucoamylase of $70 \sim 190 \mu$ was much inferior to those of native enzyme and BAC-glucoamylase of $0 \sim 15 \mu$ in the range of pH $2 \sim 4$ and was slightly inferior in the range of $\mathrm{pH}$ $8 \sim 10$.

5. Urea stability. The reaction rates in the presence of urea were assayed and the

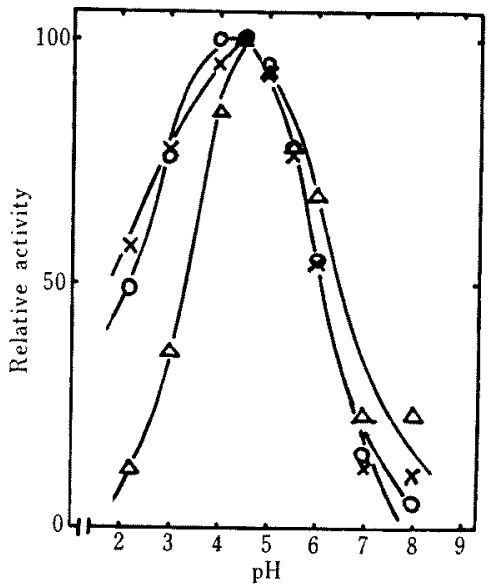

FIG. 8. pH-Activity Curves.

The enzyme assay (maltose as substrate) was carried out under standard conditions except for buffer employed. Respectively, $79 \mu \mathrm{g}$ of native glucoamylase, $4.0 \mathrm{mg}$ (bound enzyme $174 \mu \mathrm{g}$ ) of BAC-glucoamylase of $0 \sim 15 \mu$ and $8.7 \mathrm{mg}$ (bound enzyme $156 \mu \mathrm{g}$ ) of BAC-glucoamylase of $70 \sim$ $190 \mu$ were used for the enzyme assay. At pH $2.20 \sim 3.0, \mathrm{pH} 4.0 \sim 5.5$ and $\mathrm{pH} 6.0 \sim 8.0$, tartarate buffer, acetate buffer and phosphate buffer of 0.5 of ionic strength were used, respectively.

$x-x$ Native glucoamylase; $O-O$ BAC-glucoamylase of $0 \sim 15 \mu ; \triangle-\triangle \mathrm{BAC}$-glucoamylase of $70 \sim 190 \mu$.

results are shown in Fig. 10. It was found that the stability of BAC-glucoamylase of $0 \sim 15 \mu$ in the presence of urea was almost identical to that of native enzyme, however the stability of BAC-glucoamylase of $70 \sim$ $190 \mu$ against urea was much inferior to the former.

\section{DISCUSSION}

The preparation of immobilized trypsin and chymotrypsin by coupling with halogenacetyl cellulose (HAC) was reported by A. Patchornik, ${ }^{7}$ however the preparation has not been investigated in detail up to this time. The authors prepared immobilized glucoamylase by HAC according to A. Patchornik's method. However, the activity and the protein content 


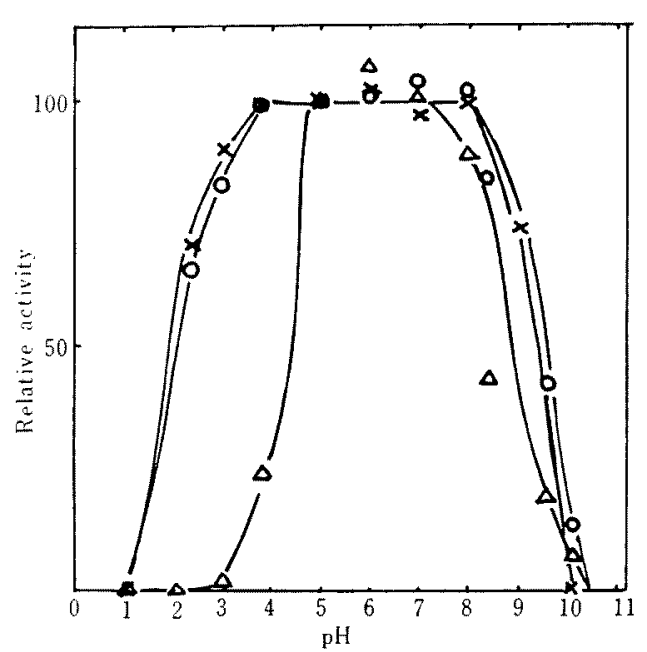

FIG. 9. $\mathrm{pH}$ Stability.

A mixture of $1 \mathrm{ml}$ of enzyme solution or the suspension and $1 \mathrm{ml}$ of 0.2 of ionic strength of buffer was incubated for $48 \mathrm{hr}$ at $30^{\circ} \mathrm{C}$ and after adjusting to about $\mathrm{pH} 4.5$, the enzyme assay (maltose as substrate) was carried out under standard conditions. At $\mathrm{pH} 1.4, \mathrm{pH} 2.4 \sim 3.0$, $\mathrm{pH} \quad 3.8 \sim 5.0, \mathrm{pH} \quad 6.0 \sim 8.0$ and $\mathrm{pH} \quad 8.4 \sim 10.1$, hydrochloric acid-acetic acid buffer, tartarate buffer, acetate buffer, phosphate buffer and ammonium buffer were used, respectively. Respectively, $79 \mu \mathrm{g}$ of native glucoamylase, $8.0 \mathrm{mg}$ (bound enzyme 348, g) of BAC-glucoamylase of $0 \sim 15 /$ and 13.3 $\mathrm{mg}$ (bound enzyme $340 \mu \mathrm{g}$ ) of BAC-glucoamylase of $70 \sim 190$ " were used for the enzyme assay.

$x-x$ Native glucoamylase: $0-0$ BAC-glucoamylase of $0 \sim 15 \mu ; \triangle-\triangle$ BAC-glucoamylase of $70-190 \mu$. of the BAC-glucoamylase were low. Accordingly, as a result of investigation of the improvement to increase the activity and the protein content, the authors improved A. Patchornik's method as follows. HAC was at first suspended in organic solvents, such as DMSO and methylcellosolve, and was plenti-

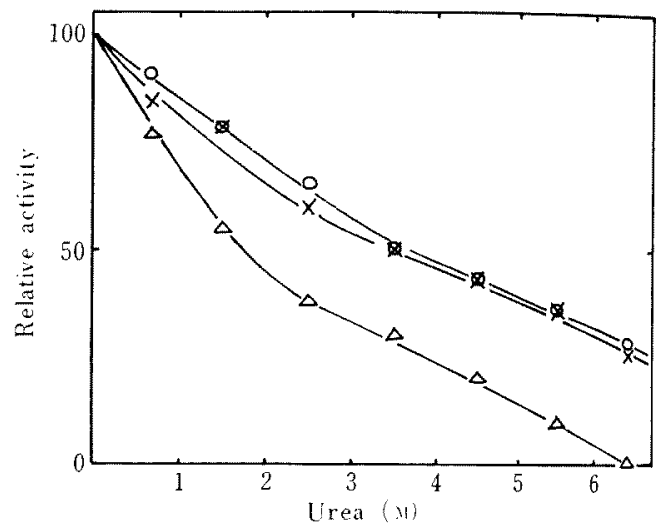

FIG. 10. Effect of Urea Concentration on the Reaction Rate.

The enzyme assay (maltose as substrate) was carried out under standard conditions in presence of each urea concentration. Respectively, $79 \mu \mathrm{g}$ of native glucoamylase, $5.1 \mathrm{mg}$ (bound enzyme $230 \mu \mathrm{g})$ of BAC-glucoamylase of $0 \sim 15 \mu$ and 13.3 $\mathrm{mg}$ (bound enzyme $340 \mu \mathrm{g}$ ) of BAC-glucoamylase were used for the enzyme assay.

$x$ - $x$ Native glucoamylase; $0-0$ BAC-glucoamylase of $0 \sim 15 \mu ; \triangle-\triangle$ BAC-glucoamylase of $70 \sim 190 \mu$.

Table VI. Particle Size of BaC-Glucoamylase (1)

BAC-glucoamylase of $0-15 /$ (A)

\begin{tabular}{lccc}
\multicolumn{2}{c}{ Particle size } & The number frequency \\
$\begin{array}{c}\text { Range of } \\
\text { diameter }(/ \mu)\end{array}$ & $\begin{array}{c}\text { Mean } \\
\text { diameter }(/ 1)\end{array}$ & $\begin{array}{c}\text { The weight frequency } \\
\text { distribution }(\%)\end{array}$ \\
$0 \sim 5$ & 2.5 & 988 & 14 \\
$5 \sim 10$ & 7.5 & 108 & 38 \\
$10 \sim 15$ & 12.5 & 28 & 48 \\
total & & 1124 & 100
\end{tabular}

The above BAC-glucoamylase was prepared under standard preparation by using DMSO as solvent and was fractionated. 
BAC-glucoamylase of $0 \sim 15 \mu(\mathrm{B})$

\begin{tabular}{cccc}
\multicolumn{2}{c}{ Particle size } & $\begin{array}{c}\text { The number frequency } \\
\text { distribution (number) }\end{array}$ & $\begin{array}{c}\text { The weight frequency } \\
\text { distribution }(\%)\end{array}$ \\
$\begin{array}{c}\text { Range of } \\
\text { diameter }(\mu)\end{array}$ & $\begin{array}{c}\text { Mean } \\
\text { diameter }(\mu)\end{array}$ & 2208 & 22 \\
\hline $0 \sim 5$ & 2.5 & 253 & 68 \\
$5 \sim 10$ & 7.5 & 6 & 7 \\
$10 \sim 15$ & 12.5 & 1 & 3 \\
$15 \sim 20$ & 17.5 & 2473 & 100 \\
total & &
\end{tabular}

The above BAC-glucoamylase was prepared under standard preparation after crashing $300 \mathrm{mg}$ of $\mathrm{BAC}$ with $300 \mathrm{mg}$ of silica sand in mortar and was fractionated. Organic solvent was not used.

BAC-glucoamylase of $0 \sim 15 \mu(\mathrm{C})$

\begin{tabular}{cccc}
\hline \multicolumn{1}{c}{ Particle size } & $\begin{array}{c}\text { The number frequency } \\
\text { distribution (number) }\end{array}$ & $\begin{array}{c}\text { The weight frequency } \\
\text { distribution }(\%)\end{array}$ \\
$\begin{array}{c}\text { Range of } \\
\text { diameter }(\mu)\end{array}$ & $\begin{array}{c}\text { Mean } \\
\text { diameter }(\mu)\end{array}$ & 3433 & 21 \\
$0 \sim 5$ & 2.5 & 272 & 44 \\
$5 \sim 10$ & 7.5 & 39 & 29 \\
$10 \sim 15$ & 12.5 & 3 & 6 \\
$15 \sim 20$ & 17.5 & 3747 & 100 \\
total & & & 0
\end{tabular}

The above BAC-glucoamylase was prepared under standard preparation except for using $20 \mathrm{mg}$ of glucoamylase after crashing as described the above and was fractionated. Organic solvent was not used.

Table Vil. Particle Size of BaC-Glucoamylase (2)

BAC glucoamylase of $15 \sim 55 \mu$.

\begin{tabular}{cccc} 
Particle size & $\begin{array}{c}\text { Mean } \\
\begin{array}{c}\text { Range of } \\
\text { diameter }(\mu)\end{array}\end{array}$ & $\begin{array}{c}\text { The number frequency } \\
\text { distribution (number) } \\
\text { diameter }(\mu)\end{array}$ & $\begin{array}{c}\text { The weight frequency } \\
\text { distribution }(\%)\end{array}$ \\
\hline $0 \sim 10$ & 5 & 81 & 0 \\
$10 \sim 20$ & 15 & 149 & 18 \\
$20 \sim 30$ & 25 & 56 & 31 \\
$30 \sim 40$ & 35 & 18 & 27 \\
$40 \sim 50$ & 45 & 6 & 19 \\
$50 \sim 60$ & 55 & 1 & 6 \\
total & & 311 & 101
\end{tabular}

The above BAC-glucoamylase was prepared under standard preparation without organic solvent and was fractionated. 
BAC-glucoamylase of $70 \sim 190 \mu$ and BAC-glucoamylase of $130 \sim 270 \mu$.

\begin{tabular}{|c|c|c|c|c|c|}
\hline \multicolumn{2}{|c|}{ Particle size } & \multicolumn{2}{|c|}{$\begin{array}{l}\text { The number frequency } \\
\text { distribution (number) }\end{array}$} & \multicolumn{2}{|c|}{$\begin{array}{l}\text { The weight frequency } \\
\text { distribution }(\%)\end{array}$} \\
\hline $\begin{array}{c}\text { Range of } \\
\text { diameter }(\mu)\end{array}$ & $\begin{array}{c}\text { Mean } \\
\text { diameter }(/ 1)\end{array}$ & $\begin{array}{c}70 \sim 190 \mu \text { of } \\
\text { BAC- } \\
\text { glucoamylase }\end{array}$ & $\begin{array}{c}130 \sim 270 \mu \text { of } \\
\text { BAC- } \\
\text { glucoamylase }\end{array}$ & $\begin{array}{c}70 \sim 190 \mu \text { of } \\
\text { BAC- } \\
\text { glucoamylase }\end{array}$ & $\begin{array}{c}130 \sim 270 \mu \text { of } \\
\text { BAC- } \\
\text { glucoamylase }\end{array}$ \\
\hline $0 \sim 20$ & 10 & 22 & - & - & - \\
\hline $20 \sim 40$ & 30 & 127 & 1 & 1 & - \\
\hline $40 \sim 60$ & 50 & 114 & 8 & 2 & - \\
\hline $60 \sim 80$ & 70 & 88 & 18 & 5 & - \\
\hline $80 \sim 100$ & 90 & 87 & 28 & 11 & 1 \\
\hline $100 \sim 120$ & 110 & 76 & 42 & 17 & 2 \\
\hline $120 \sim 140$ & 130 & 50 & 59 & 19 & 6 \\
\hline $140 \sim 160$ & 150 & 22 & 69 & 13 & 10 \\
\hline $160 \sim 180$ & 170 & 13 & 86 & 11 & 18 \\
\hline $180 \sim 200$ & 190 & 4 & 79 & 5 & 23 \\
\hline $200 \sim 220$ & 210 & 6 & 36 & 9 & 14 \\
\hline $220 \sim 240$ & 230 & 4 & 24 & 8 & 12 \\
\hline $240 \sim 260$ & 250 & - & 9 & - & 6 \\
\hline $260 \sim 280$ & 270 & - & 6 & - & 5 \\
\hline $280 \sim 300$ & 290 & - & 3 & - & 3 \\
\hline total & & 613 & 468 & 101 & 100 \\
\hline
\end{tabular}

The above BAC-glucoamylases were prepared under standard preparation.

Table Vili. Caseinolytic Activity of Trypsin Bound to Halogenacetyl Cellulose

\begin{tabular}{llccccc}
\hline & Solvent & $\begin{array}{c}\text { Yield } \\
(\mathrm{mg})\end{array}$ & $\begin{array}{c}\text { Protein content } \\
(\%)\end{array}$ & $\begin{array}{c}\text { Total activity } \\
(\mathrm{U})\end{array}$ & $\begin{array}{c}\text { Specific activity } \\
\text { (U/mg) }\end{array}$ & $\begin{array}{c}\% \text { of original } \\
\text { activity }\end{array}$ \\
\hline \multirow{2}{*}{ BAC (small)-T } & water & 288 & 2.8 & 751 & 93 & 10 \\
& acetone & 283 & 4.5 & 1,190 & 93 & 10 \\
\multirow{5}{*}{ IAC-T } & DMSO & 278 & 4.7 & 2,230 & 171 & 19 \\
& water & 294 & 2.5 & 765 & 104 & 11 \\
& acetone & 278 & 4.2 & 1,123 & 96 & 10 \\
& DMSO & 291 & 5.1 & 2,521 & 170 & 19 \\
\hline
\end{tabular}

BAC(small)-T; Trypsin bound to BAC(small). IAC-T; trypsin bound to IAC. The above immobilized trypsin was prepared by using $300 \mathrm{mg}$ of BAC or IAC and $30 \mathrm{mg}$ of trypsin (specific activity: $920 \mathrm{U} / \mathrm{mg}$ in the case of casein as substrate)

fully dissolved in organic solvents in large amount. Buffer solution was added to this solution and the dissolved $\mathrm{HAC}$ was regenerated. Glucoamylase solution was added to the suspension and the coupling reaction between glucoamylase and the regenerated $\mathrm{HAC}$ was started. Since the regenerated HAC was brittle, it was easily ground up to fine particles by stirring during the coupling reaction and very fine particles of HAC-glucoamylase were prepared. Total activity of HAC-glucoamylase prepared by this method increased by about five times and the specific activity increased by about three times, as compared with the preparation by A. Patchornik's method.

Optimum $\mathrm{pH}$ in this coupling reaction was 
observed at $\mathrm{pH} 8.4$ and higher enzyme concentration in the reaction mixture allowed to prepare higher enzyme content of the preparation.

As a result of investigating the cause of effect of organic solvents on the activity of the resulted preparation, the authors presumed that the activity of BAC-glucoamylase was much influenced by the particle size. In fact, particles of $0 \sim 15 \mu$ had much higher specific activity than that of particles over $15 \mu$ as shown in Table V. The close relation between the particle size and the specific activity was presumed by the authors in the previous paper relating to the preparation of $\mathrm{CMC}$ glucoamylase and $\mathrm{P}$. Bernfeld et al., ${ }^{12 !}$ however its relation could be proved more clearly by this experiment. The effect of organic solvent on the activity of BAC-glucoamylase was developed to the preparation of BAC-trypsin and IAC-trypsin. The results were shown in Table VIII. The effect of organic solvents on the activity and the protein content was also observed in this case.

General properties of BAC-glucoamylase of $0 \sim 15 \mu$ and $70 \sim 190 \mu$ were compared with those of native glucoamylase. $K m$ of BAC-glucoamylase increased slightly, as compared with that of native enzyme and $K m$ of large particles had a tendency to increase than it of the fine particles. Accordingly, it was concluded that the absolute $\mathrm{Km}$ of $\mathrm{BAC}$ glucoamylase could hardly be determined. The other general properties of BAC-glucoamylase of $0 \sim 15 \mu$ were almost identical to those of native enzyme except for the effect of temperature on the reaction rate to amylose. However, $\mathrm{pH}$ activity, $\mathrm{pH}$ stability and urea stability of BAC-glucoamylase of $70 \sim 190 \mu$ were much inferior to those of native one and BAC-glucoamylase of $0 \sim 15 \|$ Although the authors can not clearly explain the reason at present, it is very interesting phenomena that the specific activity and general properties of BAC-glucoamylase are influenced by the particle size of the preparation.

\section{REFERENCES}

1) T. Tosa and I. Chibata, Hakko Kyokaishi, 25, 49( 1967).

2) L. Goldstein, "Fermentation Advances," ed. by D. Perlman, Academic Press, 1969, p. 391.

3) A. Usami, T. Yamada and A. Kimura, Hakko Kyokaishi, 25, 513 (1967).

4) M. J. Batchler, G.W. Strandberg and K. L. Smiley, Biotechnology and Bioengineering, 12, 85 (1970)

5) H. Maeda and H. Suzuki, Nippon Nogeikagaku Kaishi, 44, 547 (1970).

6) H. Maeda and H. Suzuki, Hakko Kyokaishi, 28, 391 (1970).

7) A. Patchornik, U. S. Patent, 3,278,392 (1966).

8) H. Azumi and T. Nakajima, Sci. Rept. Tohoku Univ.. Ser. 1, 36, 278 (1952).

9) Y. Morita and K. Kogure, Nippon Kagaku Zasshi, 84, 816 (1963).

10) S. Ota, Japan Analyst, 15, 689 (1966).

11) S. Oka, 'Zikken Kagaku Koza,' Maruzen, 15, 259 (1958).

12) P. Bernfeld, R. E. Bieber and P. C. Macdonnell, Archives of Biochemistry and Biophysics, 127. 779 (1968). 